\title{
Pengaruh Gaya Kepemimpinan Transformasional dan Budaya Tri Hita Karana pada Kinerja LPD
}

\author{
I Putu Suarna Bumi ${ }^{1}$ \\ Fakultas Ekonomi dan Bisnis \\ Universitas Udayana, Indonesia. \\ Email: suarnabumi17@gmail.com
}

\author{
I Wayan Suartana ${ }^{2}$ \\ Fakultas Ekonomi dan Bisnis \\ Universitas Udayana, Indonesia.
}

\begin{abstract}
ABSTRAK
Penelitian memiliki tujuan untuk menguji pengaruh gaya kepemimpinan transformasional dan budaya Tri Hita Karana pada kinerja Lembaga Perkreditan Desa (LPD) di Kota Denpasar yang berjumlah 35 LPD. Responden yang digunakan dalam penelitian merupakan kepala LPD, karyawan bagian tata usaha, dan kasir. Keseluruhan responden berjumlah 105 orang yang ditentukan dengan menggunakan metode sampel jenuh. Metode pengumpulan data dan teknik analisis data yang digunakan adalah metode kuesioner dan analisis regresi linear berganda. Hasil penelitian menunjukkan bahwa gaya kepemimpinan transformasional ternyata memberikan pengaruh negatif pada kinerja LPD, berbanding terbalik dengan budaya Tri Hita Karana yang memberikan pengaruh positif pada kinerja LPD di Kota Denpasar.
\end{abstract}

Kata Kunci : $\quad$ Kinerja; Kepemimpinan; Tri Hita Karana.

\section{Effect of Transformational Leadership Style and Tri Hita Karana Culture on LPD Performance}

\section{ABSTRACT}

The study aimed to examine the influence of the transformational leadership style and culture of Tri Hita Karana on the performance of the Village Credit Institutions (LPD) in Denpasar, which amounted to 35 $L P D$. Respondents used in the study were the head of the LPD, the administrative staff, and the cashier. Overall respondents numbered 105 people who were determined using the saturated sample method. Data collection methods and data analysis techniques used are questionnaire methods and multiple linear regression analysis. The results showed that the transformational leadership style apparently had a negative influence on LPD performance, inversely proportional to the culture of Tri Hita Karana which had a positive influence on LPD performance in Denpasar City.

Keywords : $\quad$ Performance; Leadership; Tri Hita Karana.

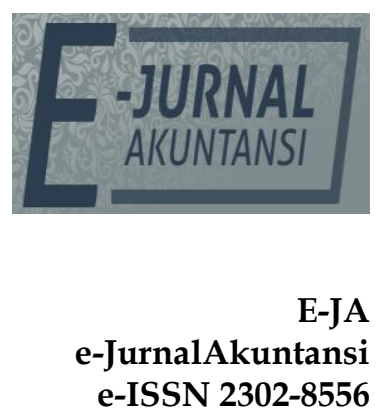

Vol. 29 No. 2

Denpasar, November 2019

Hal. 818-832

Artikel masuk: 17 Oktober 2019

Tanggal diterima: 20 November 2019 


\section{PENDAHULUAN}

Lembaga Perkreditan Desa (LPD) merupakan salah satu bentuk keunikan budaya Bali sebagai lembaga perekonomian masyarakat Bali yang dicetuskan pertama kalinya oleh Gubernur Bali, Prof.Dr.Ida Bagus Mantra pada tahun 1984. Lembaga ini dimiliki oleh hampir seluruh desa yang ada di Bali, dan terbukti telah mampu mewujudkan pemerataan perekonomian masyarakat Bali dari tingkat pedesaan hingga di kota besar. Lembaga Perkreditan Desa merupakan satu-satunya lembaga keungan skala kecil yang dimiliki oleh komunitas adat di Bali dengan sistem ekonomi khas Bali yakni bebanjaran (Suartana, 2013). Lembaga ini didirikan dengan tujuan utama adalah membantu pengelolaan keuangan desa dan masyarakat kecil serta membantu memberikan pinjaman modal usaha bagi masyarakatnya.

Budaya Tri Hita Karana melekat pada landasan LPD sebagai lembaga keungan berbasis adat di Bali (Satyawati \& Suartanna, 2014). Pernyataan tersebut menunjukkan bahwa LPD merupakan lembaga keuangan yang berlandaskan budaya dan adat Bali serta menjunjung tinggi kepercayaan masyarakat Bali.Sebagai lembaga keuangan yang dekat dengan kehidupan masyarakat desa pakraman, kinerja LPD diharapkan mampu membantu dan mengayomi masyarakat Bali terutama dalam bidang perekonomian.Melihat hal tersebut sangat tepat jika dikatakan bahwa LPD memegang peran dan fungsi yang sangat penting, sehingga menjaga keberlangsungan LPD agar tetap eksis dan sesuai dengan kebutuhan masyarakat sangatlah vital.Selain itu hal yang tak kalah penting yang harus diperhatikan dalam pengelolaan LPD adalah memberikan pelayanan terbaik kepada masyarakat sehingga mampu menarik kepercayaan masyarakat untuk menggunakan jasa LPD setempat.

Peran dan fungsi LPD yang sangat penting membuatnya harus mampu meningkatkan kinerja dan pelayanan. Namun data dari Lembaga Pemberdayaan Lembaga Perkreditan Desa (LPLPD) Kota Denpasar Tahun 2015 mencatat bahwa terdapat sedikitnya 1 LPD dengan kategori tidak sehat di Denpasar Selatan, dan 2 LPD yang dinyatakan cukup sehat di Denpasar Selatan dan Utara. Data tersebut memberikan informasi bahwa masih adanya kekurangan dan masalah yang dialami LPD, dimana masalah tersebut mampu mempengaruhi kinerja LPD dalam memberikan pelayanan yang terbaik bagi masyarakat desa. Layanan utama yang ditawarkan LPD adalah pemberian bantuan berupa kredit kepada masyarakat yang kekurangan dana, sehingga masalah utama yang sering kali dialami LPD adalah adanya kredit macet. Kredit macet didefinisikan sebagai kredit yang bermasalah, yang sulit untuk ditagih. Penentuan tingkat kredit bermasalah ini dilihat dari Non Performing Loan (NPL) yaitu membandingkan antara kredit macet dengan total seluruh kredit yang diberikan LPD.

Keberhasilan pengelolaan LPD salah satunya dipengaruhi oleh peran serta pemimpin dalam membimbing dan mendorong sumber daya manusia, modal, nasabah, dan penunjang lainnya dalam mencapai tujuan organisasi. Gaya kepemimpinan menunjukkan kualitas pemimpin (Asmara \& Widanaputra, 2017). Gaya kepemimpinan hendaknya sesuai dengan keadaan di dalam organisasi, dan sesuai dengan para karyawan, sehingga dapat meningkatkan kinerja karyawan. Gaya kepemimpinan diartikan sebagai metode atau cara yang digunakan pemimpin dalam memberikan pengaruh kepada lingkungan di 
sekitarnya. Sasaran utama setiap gaya kepemimpinan yang diterapkan adalah respon yang baik dari bawahan yang akan melaksanakan setiap visi dan misi organisasi. Untuk itulah, karyawan pada masa sekarang ini tidak hanya dilihat sebagai subjek untuk menghasilkan keuntungan bagi perusahan melainkan juga sebagai salah satu aset yang penting bagi perusahaan. Gaya kepemimpinan yang sesuai harus diperhatikan sebagai salah satu cara untuk menjaga aset perusahaan ini. Metode kepemimpinan yang tradisional kini telah digantikan oleh gaya kepemimpinan transformasional yang lebih moderen, dimana pemimpin melakukan transformasi secara langsung terkait ide dan gagasannya untuk dapat dilaksanakan oleh setiap karyawan. Namun tipe ini terkesan kaku, karena setiap instruksi yang diberikan oleh pemimpin mau tidak mau harus dilaksanakan oleh bawahannya secara mutlak (Yukl, 2013).

Faktor lain yang tidak kalah penting terkait kinerja suatu lembaga adalah budaya yang dikembangkan dan dilaksanakan secara turun temurun dalam perusahaan. Budaya organisasi mencerminkan kebiasan-kebiasaan yang diterima dalam organisasi, yang mutlak harus diikuti seluruh anggota. Bali yang terkenal akan adat dan budayanya memiliki salah satu budaya yang menjadi landasan berperilaku masyarakat yang dikenal dengan sebutan Tri Hita Karana (Riana, 2011). Dalam menjalankan kehidupan sehari-hari, umat di Bali selalu berpegang teguh pada tiga harmonis yang dijelaskan dalam ajaran Tri Hita Karana, diantaranya Parahyangan yakni hubungan harmonis manusia dengan Tuhan, Palemahan yakni hubungan harmonis antara manusia dengan lingkungan, dan Pawongan yakni hubungan harmonis antara manusia dengan sesamanya.

Penelitian terkait isu gaya kepemimpinan, dan budaya organisasi pada kenyataannya menunjukkan hasil yang berbeda atau inkonsisten. Beberapa diantaranya adalah penelitian Risqi, et al., (2015) yang memperoleh hasil bahwa gaya kepemimpinan dan budaya organisasi dapat meningkatkan kinerja, namun bertolak belakang dengan hasil oleh Susantoso, (2013) serta Parlinda \& Wahyuddin, (2004) yang menemukan bahwa kedua variabel tersebut justru menurunkan kinerja organisasi.

Ketidakkonsistenan hasil penelitian serta adanya beberapa LPD di Kota Denpasar yang masih memiliki kendala memberikan inspirasi penulis untuk melakukan penelitian terkait gaya kepemimpinan transformasional yang belakangan ini diterapkan dan budaya Tri Hita Karana yang melandasi setiap aspek kehidupan masyarakat Bali pada kinerja LPD di Kota Denpasar.

Teori stewardship memfokuskan perhatian pada perilaku manajer yang mengutamakan kepentingan organisasi daripada kepentingan pribadi (Keay, 2017). Dalam teori ini steward dan principal memiliki tujuan yang berbeda, namun pihak steward akan lebih memilih untuk bekerjasama mengikuti keinginan principal, karena pada dasarnya steward memiliki keyakinan bahwa keinginan principal adalah semata-mata untuk tercapainya tujuan organisasi (Subramanian, 2018). Konsep penting yang harus diketahui dalam teori ini adalah, meskipun steward secara sukarela mengikuti keinginan principal, namun bukan berarti steward tidak memiliki tujuan masing-masing yang mungkin berbeda dengan principal. Teori ini dapat diterapkan dalam organisasi sektor publik (Madison, 2014). 
Hubungan teori ini dengan penelitian adalah pertimbangan bahwa teori stewardship dapat menjelaskan perilaku pengurus LPD (steward) yang diharapkan mampu mengesampingkan kepentingan pribadi demi tercapainya tujuan LPD. Demikian pula masyarakat desa sebagai steward yang telah diberikan bantuan dana oleh pihak LPD untuk dapat memanfaatkan dana tersebut dan mempertanggungjawabkan pengembaliannya pada pihak LPD. Pengelolaan LPD tidak terlepas dari adanya kepentingan masing-masing pengurus LPD.Namun, sesuai dengan teori stewardship antara pengurus LPD dan pemimpin LPD hendaknya berkerjasama secara kolektif.Pengurus LPD berjalan sesuai dengan arahan pemimpin, dan pemimpin melakukan tugas untuk sebesar-besarnya kepentingan keberlangsungan operasional LPD, sebagai penggerak ekonomi masyarakat desa.

Kepemimpinan merupakan bagian yang tidak dapat dilepaskan dari organisasi. Setiap organisasi pasti dan harus memiliki seorang pemimpin yang akan mengatur jalannya organisasi, mulai dari mengatur strategi, mengatur bawahan, dan seluruh pendukung organisasi untuk mencapai tujuan (Pratiwi \& Erawati, 2017). Kepemimpinan menurut Hasibuan, (2009) merupakan proses memberikan pengaruh kepada orang untuk mengerti dan menyetujui tugas yang akan dikerjakan, cara melakukan tugas secara efektif, dan memfasilitasi usaha individu dan kelompok dalam mencapai tujuan bersama. Kepemimpinan merupakan sebuah keterampilan dalam mempengaruhi orang lain, memberikan motivasi dan semangat, membimbing orang lain untuk mau bekerjasama mencapai visi dan misi organisasi (Kouszes \& Posner, 2004).

Kepemimpinan pertama kali timbul dikarenakan adanya keterbatasan dalam diri manusia, sehingga mulai muncul keinginan untuk memimpin dan dipimpin (Einolander, 2015). Pemimpin adalah orang yang mengendalikan dan bertanggung jawab atas operasi sebuah organisasi dan pemimpin yang baik dapat ditetapkan optimis tujuan dan sasaran sambil mengarahkan operasi perusahaan menuju tujuan tersebut melalui strategi yang efektif. Selain itu, pemimpin yang baik bisa juga memengaruhi karyawan mereka dan memotivasi mereka memperkuat budaya organisasi yang positif dan melalui manfaat karyawan yang murah hati, misalnya kesehatan asuransi perawatan, kompensasi pekerja, manfaat cuti dan lainnya (Hao \& Yazdanifard, 2015). Seseorang dengan kepemimpinan yang kuat kemampuan akan menjadi contoh atau panutan yang baik bagi mereka karyawan, karena pemimpin yang mampu secara efektif mencapai beberapa hasil baik atau pencapaian hasil kepercayaan dan kekaguman karyawan mereka, dan secara tidak sengaja mengubah nilai, kepercayaan, dan perilaku mereka dan sikap, sebagai bentuk sanjungan yang tulus.

Kepemimpinan transformasional adalah proses di mana para pemimpin meyakinkan pengikut untuk menginvestasikan upaya ekstra, membantu mereka mengembangkan pengetahuan profesional, keterampilan, dan merangsang mereka untuk secara kreatif menangani masalah yang kompleks (Hunt, 2014). Kepemimpinan transformasional telah dikaitkan dengan pekerjaan berkinerja tim yang tinggi, peningkatan perawatan pasien dan kinerja keselamatan perawat (Giddens, 2018). Selain dampak langsung kepemimpinan pada kinerja, komitmen organisasi afektif dan perilaku kewargaan organisasi, hubungan 
kepemimpinan transformasional dan hasil juga telah diperiksa dimoderasi oleh pengayaan pekerjaan, penetapan tujuan dan karakteristik pekerjaan, keterlibatan kerja, keinginan berpindah. Pengikut yang mengalami perilaku yang memotivasi dan peduli dari pemimpin mereka menjadikan hubungan pertukaran anggota pemimpin mereka sangat berharga karena mereka menganggap pemimpin mereka dapat diandalkan dan dapat dipercaya dalam proses pertukaran (Jyoti \& Bhau, 2016).

Budaya Tri Hita Karana merupakan salah satu adat dan budaya Bali yang sampai saat ini masih tetap dijadikan landasan dalam beperilaku bagi masyarakat Bali. Budaya ini menekankan pada perilaku yang seharusnya dijaga oleh setiap masyarakat demi mewujudkan hubungan yang harmonis, kepada Sang Pencipta, kepada lingkungan dan kepada sesama manusia. Dalam organisasi menjaga hubungan yang harmonis dengan sesama anggota sangatlah penting demi kelangsungan organisasi. Tak terkecuali organisasi LPD yang merupakan organisasi berbasis di desa pakraman di Bali, yang harus mampu melaksanakan budaya Tri Hita Karana oleh setiap bagian organisasi (Suardhika, et al., 2012).

Efektivitas dan efisiensi dari kegiatan organisasi dapat dinilai dari kinerja keuangannya (Arifin, 2015). Kinerja keuangan merupakan hal paling mendasar dan paling mudah untuk dilihat dalam tujuan menentukan keberhasilan suatu organisasi (Pertiwi \& Pratama, 2011). Kinerja suatu organisasi apakah meningkat atau justru menurun dapat dilihat dari laporan keuangan yang memberikan berbagi macam informasi keuangan, dimana informasi tersebutlah yang biasanya dijadikan sebagai pedoman bagi manajemen untuk meningkatkan atau memperbaiki strategi organisasi, dan memberikan reward maupun punishment bagi manajer dan anggota organisasi lainnya atas kinerja mereka. Untuk mengukur kinerja finansial organisasi biasanya dengan cara melihat profitabilitas usaha, yang menunjukkan tingkat laba yang diterima perusahaan pada periode tertentu. Organisasi sektor publik seperti LPD lebih memfokuskan pada tingkat pengembalian aset sebab sebesar $60 \%$ dari total aset akan digunakan dalam operasional LPD yaitu menyalukannya kembali kepada masyarakat, sehingga formula yang lebih diperhatikan adala rasio ROE (Return On Equity). Kinerja keuangan merupakan pengukuran keberhasilan perusahaan menggunakan alat analisis keuangan, sehingga dapat diketahui peningkatan maupun penurunan kinerja perusahaan (Ingdanata, 2017).

Kepemimpinan adalah ketika pemimpin membimbing karyawan mereka menuju tujuan organisasi, sambil berusaha untuk berkomunikasi dan memotivasi karyawan mereka untuk memastikan karyawan mereka berada di posisi yang tepat untuk menggunakan bakat mereka dan berkomitmen untuk pekerjaan mereka. Strategi kepemimpinan juga akan berubah sesuai dengan tren saat ini jika diperlukan, tidak seperti manajemen yang hanya mengikuti aturan lama dan tradisional tersebut (Atkinson \& Mackenzie, 2015). Jika tidak ada kepemimpinan yang efektif dalam suatu organisasi tidak akan ada perubahan, karena tidak ada pemimpin yang memotivasi dan memimpin karyawan organisasi serta memberikan arahan yang jelas bagi organisasi (Solomon \& Steyn, 2017). 
Teori stewardship menyatakan bahwa steward akan mengutamakan kepentingan organisasi di atas kepentingan pribadi. Pemimpin LPD dalam penelitian ini jika dikaitkan dengan teori stewardship, maka memiliki kewajiban untuk memimpin bawahan untuk bekerjasama mencapai tujuan LPD. Meskipun pada kenyataannya steward memiliki kepentingan pribadi, namun pemimpin harus selalu mengutamakan kepentingan organisasi LPD. Penelitian yang menyatakan bahwa gaya kepemimpinan transformasional memberikan pengaruh positif pada kinerja adalah penelitian oleh Suharyanto, (2011) yang didukung oleh penelitian dari (Astuti, 2015).

Berdasarkan hal tersebut maka rumusan hipotesis pertama dalam penelitian ini yakni.

$\mathrm{H}_{1}$ : Kepemimpinan Transformasional berpengaruh positif pada Kinerja Keuangan.

Budaya organisasi telah diidentifikasi sebagai sumber daya tak berwujud yang penting dan penghalang untuk meniru dengan efek yang kuat pada kinerja (Vveinhardt \& Andriukaitiene, 2017). Budaya organisasi memainkan fungsi utama dalam memodelkan perilaku dan kinerja perusahaan melalui upaya kolektif masing-masing anggota organisasi. Budaya suatu organisasi digambarkan oleh gaya kepemimpinan yang dominan, komunikasi, proses organisasi, struktur, sistem, dan definisi unik keberhasilan dalam pandangan organisasi tertentu (Tianya, 2015). Nilai dan keyakinan menentukan struktur dan sistem yang dibuat dalam suatu organisasi dan bagaimana orang berperilaku terhadap satu sama lain. Sebaliknya, struktur dan sistem mempengaruhi sikap anggota organisasi (Joseph \& Kibera, 2019).

Tri Hita Karana merupakan budaya dan filsafat masyarakat Bali dalam berperilaku, yakni selalu menjaga hubungan baik dengan 3 komponen dalam hidup yakni Tuhan, lingkungan dan sesama manusia. Sebagai lembaga yang lahir atas dasar dari budaya dan adat masyarakat Bali, LPD juga mewarisi nilainilai budaya Bali Tri Hita Karana dalam menjalankan kegiatan organisasi, sehingga nilai LPD dan nilai masyarakat merupakan kesatuan yang homogen.

Penelitian terkait budaya Tri Hita Karana pada kinerja organisasi yang berpengaruh positif diperoleh oleh penelitian (Gunawan, 2009). Sejalan dengan penelitian itu, Saputra, (2012) memperoleh hasil bahwa budaya Tri Hita Karana yang diadopsi menjadi budaya organisasi oleh organisasi mampu meningkatkan kinerja organisasi.

Sesuai dengan hal tersebut, maka rumusan hipotesis kedua dalam penelitian ini adalah.

$\mathrm{H}_{2}$ : Budaya Tri Hita Karana berpengaruh positif pada Kinerja Keuangan.

\section{METODE PENELITIAN}

Desain penelitian ini menggambarkan bahwa gaya kepemimpinan transformasional dan budaya Tri Hita Karana diduga berpengaruh positif pada kinerja keuangan LPD. Hal ini didasarkan pada hasil penelitian terdahulu yang memperolah kesimpulan bahwa kedua variabel tersebut ternyata memberikan pengaruh positif.Secara sistematis, desain penelitian yang digunakan pada penelitian ini dapat digambarkan sebagai berikut. 


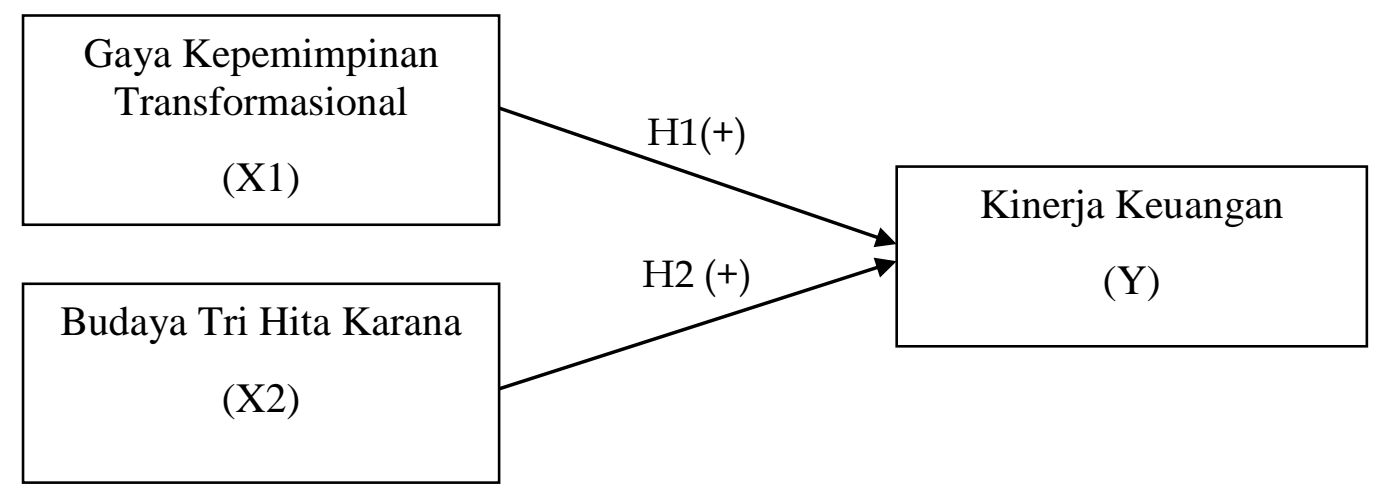

Sumber : Data Penelitian, 2019

Gambar 1. Desain Penelitian

Penelitian ini mengambil lokasi di LPD yang tersebar di Kota Denpasar dengan jumlah 35 LPD.Subjek penelitian terdiri atas kepala LPD, Tata Usaha, dan kasir LPD. Objek penelitian ini adalah kinerja ROE pada LPD di Kota Denpasar yang dipengaruhi oleh gaya kepemimpinan transformasional, dan budaya Tri Hita Karana. Variabel gaya kepemimpinan transformasional diukur dengan beberapa indikator, diantaranya kharisma, motivasi inspiratif, stimulasi intelektual, dan individual consideration. Pengukuran instrumen menggunakan skala likert 4 poin yang diadopsi dari penelitian (Pratiwi \& Erawati, 2017). Variabel budaya Tri Hita Karana diukur dengan menggunakan indikator yang diambil dari bagian-bagian Tri Hita Karana yaitu Parahyangan, Palemahan, dan Pawongan. Instrumen diukur dengan skala likert 4 poin yang diadopsi dari penelitian (Suardhika, et al., 2012). Variabel kinerja keuangan diukur dengan indikator ROE untuk menilai kinerja finansial LPD, dengan rumus sebagai berikut.

$\mathrm{ROE}=\frac{\text { LabaBersih }}{\text { ModalSendiri }} \times 100 \%$

Populasi dalam penelitian ini adalah seluruh LPD di Kota Denpasar yang berjumlah 35 LPD.Sampel ditentukan dengan metode sampel jenuh sehingga semua anggota populasi yang berjumlah 105 orang dijadikan sebagai sampel penelitian.Masing-masing LPD diambil 3 orang responden yang terdiri dari Kepala LPD, Tata Usaha, dan Kasir. Beberapa pertimbangan dalam menentukan responden adalah, kepala LPD dipilih karena kepala LPD menjalankna fungsi kepemimpinan yang memiliki tanggungjawab kepada desa pakraman, tata usaha diplih karena bertanggungjawab kepada kepala LPD dan membawahi bagian administrasi dan pembukuan, serta kasir dipilih karena kasir menjalankan fungsi pengeluaran dan penerimaan uang dari nasabah (Kartika \& Jember, 2017). Sampel ditentukan dengan metode sampel jenuh sehingga semua anggota populasi yang berjumlah 105 orang dijadikan sebagai sampel penelitian.

Data dikumpulkan dengan menggunakan metode kuesioner dan dokumentasi.Data dianalisis menggunakan analisis regresi linear berganda seperti yang dirumuskan sebagai berikut.

$Y=\alpha+\beta_{1} X_{1}+\beta_{2} X_{2}+\beta_{3} X_{3}+e$ 
Keterangan:

$\mathrm{Y} \quad=$ Kinerja Keuangan

$\mathrm{X}_{1} \quad=$ Gaya kepemimpinan transformasional

$X_{2} \quad=$ Budaya Tri Hita Karana

$\beta_{1} \quad=$ Koefesien gaya kepemimpinan transformasional

$\beta_{2} \quad=$ Koefesien budaya Tri Hita Karana

$\mathrm{a} \quad=$ Konstanta

e $\quad=$ Standard error

\section{HASIL DAN PEMBAHASAN}

Lembaga Perkreditas Desa (LPD) dibentuk sebagai wadah untuk menghimpun dana dan memberikan kredit pinjaman bagi masyarakat desa sehingga kredit tersebut nantinya diharapkan dapat digunakan untuk keperluan usaha dan mampu meningkatkan perekonomian desa secara umum. Budaya dan adat masyarakat desa pakraman menjadi nafas dan landasan pelayanan LPD.Homogenitas nilai yang berlaku di LPD dan nilai-nilai masyarakat menyebabkan LPD dengan mudah dapat memperoleh kepercayaan masyarakat. Penelitian dilakukan dengan menyebarkan kuesioner ke 105 responden, dimana masing-masing LPD mendapat 3 buah kuesioner yang ditujukan kepada kepala LPD, tata usaha, dan kasir. Rincian pendistribusian dan pengembalian kuesioner ditunjukkan pada tabel 1 .

Tabel 1.Tingkat Pengembalian Kuesioner

\begin{tabular}{lc}
\multicolumn{1}{c}{ Keterangan } & Jumlah \\
\hline Jumlah kuesioner yang disebar & 105 \\
Kuesioner yang dikembalikan & 105 \\
Tingkat pengembalian : & $100 \%$
\end{tabular}

Kuesioner yang kembali X $100 \%$

Kuesiner yang disebar

Tingkan pengembalian yang digunakan :

$100 \%$

Kuesioner yang digunakan X 100\%

Kuesioner yang disebar

Sumber : Data Penelitian, 2019

Tabel 1 menunjukkan bahwa jumlah kuesioner yang disebar adalah 105 kuesioner. Seluruh kuesioner yang disebar digunakan dalam penelitian ini.Kuesioner sebanyak 105 memiliki karakteristik responden yang beragam, seperti beragam umur, jenis kelamin, latar belakang pendidikan, dan lamanya bekerja di LPD masing-masing. Berikut tabel 2 akan menunjukkan karakteristik responden LPD di Kota Denpasar.

Uji validitas intrumen penting dilakukan sebelum melakukan analisis lebih lanjut, untuk memastikan bahwa instrumen penelitian layak untuk digunakan dalam penelitian. Instrumen yang dikatakan lolos uji ini memiliki nilai Pearson Correlation di atas 0,30 . 
Tabel 2. Karakteristik Responden

\begin{tabular}{cccc}
\hline Karakteristik & Klasifikasi & Jumlah (orang) & Persentase \\
\hline Umur & $<21$ tahun & 1 & $1 \%$ \\
& $21-30$ tahun & 36 & $34,3 \%$ \\
& $31-40$ tahun & 47 & $44,7 \%$ \\
& $41-50$ tahun & 19 & $18,1 \%$ \\
& $>50$ tahun & 2 & $1,9 \%$ \\
Karakteristik & Jumlah & 105 & $100 \%$ \\
Jenis Kelamin & Klasifikasi & Jumlah (orang) & Persentase \\
& Laki-Laki & 56 & $53,3 \%$ \\
Latar Belakang & Perempuan & 49 & $46,7 \%$ \\
Pendidikan & Jumlah & 105 & $100 \%$ \\
& SMA & 78 & $74,3 \%$ \\
Lama Bekerja & Diploma & 25 & $23,8 \%$ \\
& S1 & 2 & $1,9 \%$ \\
& Jumlah & 105 & $100 \%$ \\
& $0-5$ tahun & 39 & $37,1 \%$ \\
& 6-10 tahun & 41 & $39 \%$ \\
& $11-15$ tahun & 14 & $13,3 \%$ \\
& $>15$ tahun & 11 & $10,5 \%$ \\
& Jumlah & 105 & $100 \%$ \\
\hline
\end{tabular}

Sumber : Data Penelitian, 2019

Tabel 3 menunjukkan bahwa semua komponen pernyataan dalam kuesioner lolos uji validitas, yang dilihat dari nilai Pearson Correlation di atas 0,30. Hal ini berarti bahwa seluruh pernyataan dalam masing-masing variabel penelitian layak untuk digunakan dalam penelitian. Hasil uji validitas dapat dilihat pada Tabel 3.berikut.

Tabel 3. Hasil Uji Validitas

\begin{tabular}{cccc}
\hline Variabel & Instrumen & Pearson Correlation & Keterangan \\
\hline Gaya & X1.1 & 0,755 & Valid \\
Kepemimpinan & X1.2 & 0,686 & Valid \\
Transformasional & X1.3 & 0,717 & Valid \\
(X1) & X1.4 & 0,705 & Valid \\
Budaya Tri Hita & X2.1 & 0,762 & Valid \\
Karana & X2.2 & 0,747 & Valid \\
(X2 & X2.3 & 0,763 & Valid \\
& Instrumen & Pearson Correlation & Keterangan \\
& X2.4 & 0,726 & Valid \\
& X2.5 & 0,789 & Valid \\
& X2.6 & 0,693 & Valid \\
\hline
\end{tabular}

Sumber : Data Penelitian, 2019

Uji reliabilitas digunakan untuk meyakinkan bahwa semua pernyataan instrumen dapat dipercaya dan dapat dihandalkan. Variabel penelitian memiliki koefisien cronbach's alpha yang lebih besar dari angka 0,60 sehingga pernyataan pada kuesioner tersebut dapat dikatakan reliabel. Dalam penelitian ini variabel gaya kepemimpinan transformasional (X1) memiliki nilai cronbach's alpha sebesar 0,682 di atas 0,60 sehingga pernyataan variabel X1 dapat dikatakan reliabel. Begitupula nilai cronbach's alpha variabel budaya Tri Hita Karana (X2) 0,841 di atas 0,60 , yang menunjukkan bahwa variabel X2 reliabel. 
Analisis statistik deskriptif membantu untuk memahami kecenderungan pergerakan data apakah menuju ke titik maksimum atau menuju ke titik minimumnya.Melalui analisis deskriptif ini, pembaca dapat melihat apakah hasil variabel penelitian secara keseluruhan telah sesuai dengan yang diharapkan, yang dapat dilihat melalui kecenderungan jawaban responden pada instrumen penelitian, yang dapat dilihat pada tabel 4 .

Tabel 4. Hasil Statistik Deskriptif

\begin{tabular}{lccccc}
\hline & N & Minimum & Maximum & Mean & $\begin{array}{c}\text { Std. } \\
\text { Deviation }\end{array}$ \\
\hline $\begin{array}{l}\text { Gaya } \\
\text { Kepemimpinan }\end{array}$ & 105 & 4,00 & 17,41 & 13,4136 & 2,39059 \\
$\begin{array}{l}\text { Transformasional } \\
\text { Budaya Tri }\end{array}$ & 105 & 8,09 & 24,96 & 19,3119 & 3,95780 \\
$\begin{array}{l}\text { HitaKarana } \\
\text { Kinerja Keuangan }\end{array}$ & 105 & 0,06 & 0,75 & 0,2521 & 0,11025 \\
Valid N (listwise) & 105 & & & & \\
\hline
\end{tabular}

Sumber: Data Penelitian, 2019

Variabel gaya kepemimpinan transformasional memiliki rata-rata 13,4136 lebih cenderung mendekati nilai maksimum 17,41 yang menunjukkan bahwa pemimpin memiliki gaya kepemimpinan yang sesuai dengan lingkungan di LPD, dan sesuai dengan kepribadian bawahan, sehingga bawahan cenderung merasa nyaman dipimpin oleh orang dengan kepemimpinan transformasional. Variabel budaya Tri Hita Karana memiliki rata-rata 19,3119 mendekati nilai maksimum 24,96 menunjukkan seluruh pengurus LPD telah melaksanakan pekerjaan sesuai dengan ajaran Tri Hita Karana. Variabel kinerja keuangan memiliki nilai rata-rata 0,2521 mendekati nilai maksimum 0,75 yang dapat disimpulkan bahwa kinerja keungan LPD Kota Denpasar adalah baik.

Uji normalitas merupakan salah satu uji asumsi klasik yang harus dipenuhi sebelum model regresi dapat dikatakan layak untuk digunakan.Model regresi yang layak adalah yang memiliki nilai Asymp. Sig (2-tailed)>a. $(0,05)$ ketika dilakukan uji normalitas seperti yang ditunjukkan oleh tabel 5. bertujuan untuk mengetahui normal atau tidaknya distribusi variabel residual.

Tabel 5. Hasil Uji Normalitas

\begin{tabular}{cccl}
\hline Variabel & Kolmogorov-Smirnov & Sig. & Kesimpulan \\
\hline $\begin{array}{c}\text { Gaya Kepemimpinan } \\
\text { Transformasional (X1) }\end{array}$ & 1,348 & 0,053 & Data Normal \\
$\begin{array}{c}\text { Budaya Tri Hita Karana } \\
(\mathrm{X} 2)\end{array}$ & 1,196 & 0,114 & Data Normal \\
$\begin{array}{c}\text { Kinerja Keuangan (Y) } \\
\text { M }\end{array}$ & 1,144 & 0,146 & Data Normal \\
\hline
\end{tabular}

Sumber : Data Penelitian, 2019

Berdasarkan data pada tabel 5, setelah dilakukan uji normalitas semua variabel memiliki nilai signifikansi di atas 0,05 sehingga model regresi berdistribusi normal dan dipastikan layak untuk dilakukan pengujian lebih lanjut.

Uji multikoliniearitas Untuk mendeteksi ada atau tidaknya multikolinearitas dalam model regresi yaitu mempunyai angka Tolerance $>0,10$ atau mempunyai nilai VIF $<10$. Hasil uji multikolinearitas dalam penelitian ini adalah variabel gaya kepemimpinan transformasional memiliki nilai tolerance 
sebesar 0,997 dan VIF 1,004. Variabel budaya Tri Hita Karana memiliki masingmasing nilai tolerance dan VIF adalah 0,997 dan 1,004. Kedua variabel menunjukkan nilai tolerance di atas 0,1 dan nilai VIF kurang dari 10, sehingga dapat disimpulkan bahwa model regresi dapat diteliti lebih lanjut.

Untuk mengetahui ada atau tidaknya heteroskedastisitas yaitu dengan melakukan Uji Glejser. Persyaratan yang harus dipenuhi model regresi dalam uji heteroskedastisitas ini adalah nilai signifikansinya harus lebih besar dari $\alpha=0,05$, yang berarti tidak terjadi heteroskedastisitas dalam model regresi. uji heteroskedastisitas. Variabel gaya kepemimpinan transformasional dan budaya Tri Hita Karana telah teruji lolos dari gejala heteroskedastisitas dilihat dari nilai signifikansi yang di atas 0,05 yaitu masing-masing bernilai 0,775 dan 0,936. Hal ini menunjukkan bahwa model regresi dapat dilanjutkan pada analisis selanjutnya yaitu analisis regresi linear berganda.

Model regresi yang telah lulus semua uji asumsi klasik selanjutnya dilakukan uji analisis regresi linear berganda dengan tujuan untuk mengetahui pengaruh yang diberikan masing-masing variabel bebas yaitu gaya kepemimpinan transformasional dan variabel budaya Tri Hita Karana terhadap variabel terikatnya yakni kinerja keuangan di LPD. Hasil analisis regresi ini dapat diamati pada tabel 6 berikut.

Tabel 6. Hasil Analisis Regresi Linier Berganda

\begin{tabular}{|c|c|c|c|c|c|c|}
\hline \multirow{3}{*}{\multicolumn{2}{|c|}{ Model }} & & \multicolumn{2}{|c|}{ Coefficients $^{a}$} & \multirow{3}{*}{$\mathrm{T}$} & \multirow{3}{*}{ Sig. } \\
\hline & & Coefficients & $\begin{array}{l}\text { lized } \\
\text { ts }\end{array}$ & $\begin{array}{l}\text { Standardized } \\
\text { Coefficients }\end{array}$ & & \\
\hline & & & $\begin{array}{l}\text { Std. } \\
\text { Error }\end{array}$ & Beta & & \\
\hline \multirow[t]{6}{*}{1} & (Constant) & 272 & 080 & & 3,412 & 001 \\
\hline & Gaya &,- 001 & ,005 & \multirow[t]{2}{*}{,- 032} &,- 325 & ,746 \\
\hline & Kepemimpinan & & & & & \\
\hline & Transformasional & & & \multirow{3}{*}{ 001 } & \multirow{3}{*}{ 008 } & \multirow{3}{*}{ 994 } \\
\hline & Budaya Tri Hita & ,005 & ,003 & & & \\
\hline & Karana & & & & & \\
\hline & endent Variable: $\mathrm{K}$ & Keuang & & & & \\
\hline
\end{tabular}

Sumber : Data Penelitian, 2019

Berdasarkan tabel 6.dapat diketahui rumusan regresi linear berganda sebagai berikut.

$$
\mathrm{Y}=0,272-0,001 \mathrm{X} 1+0,005 \mathrm{X} 2+\mathrm{e}
$$

Nilai konstanta (a) 0,272 mengandung makna apabila variabel kinerja keuangan meningkat, maka variabel gaya kepemimpinan trasnformasiona, dan variabel budaya Tri Hita Karana juga cenderung meningkat. Nilai koefesien $\beta_{1}$ yakni koefisien variabel gaya kepemimpinan transformasional memiliki nilai negatif yang bermakna kinerja keungan justru menurun. Nilai koefesien $\beta_{2}$ yakni variabel budaya Tri Hita Karana bernilai positif, maka kinerja keuangan akan cenderung meningkat.

Nilai adjusted $R$ Square adalah 0,001 atau 0,01\% memiliki arti bahwa hanya 0,01\% kinerja keuangan dipengaruhi oleh variabel di dalam model yaitu variabel gaya kepemimpinan tranformasional dan budaya Tri Hita Karana, sedangkan sisanya sebesar $99,99 \%$ dipengaruhi oleh faktor lain yang justru tidak termasuk di dalam model. 
Hasil analisis hipotesis pertama merumuskan bahwa semakin ideal gaya kepemimpinan tranformasional yang diterapkan, maka semakin baik kinerja keuangan. Namun pada kenyataanya hal ini tidak dapat diterima, atau hipotesis tersebut ditolak oleh hasil analisis. Hal ini dapat dilihat dari nilai signifikansi variabel gaya kepemimpinan transformasional 0,746 di atas 0,05 yang artinya $\mathrm{H}_{0}$ diterima dan Ha ditolak. Hasil penelitian ini tidak sejalan dengan teori stewardship yang menyatakan bahwa bawahan mampu menyesuaikan diri dengan strategi dan pikiran pemimpin, sehingga proses kerjasama akan lebih mudah. Namun, hasil penelitian menunjukkan bahwa karyawan LPD di Kota Denpasar tidak mampu menyesuaikan diri dengan strategi pemimpin.Bawahan hanya mengandalkan perintah pemimpin tanpa adanya umpan balik.Bawahan tidak memiliki motivasi untuk meningkatkan kinerja, dan hanya menunggu arahan pemimpin sehingga arahan yang diberikan pemimpin tidak memberikan pengaruh pada kinerja organisasi.

Kepala LPD memberikan pengarahan dan sosialisasi terkait strategi organisasi untuk memberikan pengembalian aset yang maksimal.Bawahan seharusnya mampu meresapi dan memahami dengan baik kebijakan-kebijakan perusahaan, terutama karyawan bagian kolektor yang bertugas untuk mencari nasabah.Adanya kekurangan dalam koordinasi antar karyawan dengan kepala LPD menyebabkan kurang diminatinya tawaran mengenai penyimpanan dan peminjaman uang di LPD. Sehingga hal ini akan berdampak pada tidak tercapainya target nasabah sesuai dengan yang telah ditargetkan sebelumnya.

Hasil penelitian ini didukung oleh penelitian Rosmiyati, (2013) dengan hasil yang sama. Gaya kepemimpinan transformasional yang cenderung memberikan kesempatan karyawan untuk menyatakan pendapat, memberikan kebebasan bekerjasama ternyata tidak memberikan pengaruh pada kinerja.

Analisis hipotesis kedua memberikan rumusan bahwa semakin baik budaya organisasi yang diterapkan maka dapat meningkatkan kinerja keuangan. Hasil dari uji t ini yaitu nilai signifikansi sebesar 0,994 lebih besar dari alpha 0,05. $(0,994>0,05)$, artinya $\mathrm{H}_{0}$ diterima dan Ha ditolak. Hasil ini sejalan dengan teori Stewardship, kerjasama secara kolektif dalam penyelesaian masalah dan menyesuaikan pola pikir bawahan terhadap pimpinan mempererat hubungan kekeluargaan berpengaruh pada kinerja keuangan.Budaya Tri Hita Karana terbukti mampu mendorong karyawan untuk berkinerja lebih baik, karena budaya ini adalah budaya yang telah mengakar dan diadopsi dari nilai-nilai budaya masyarakat setempat yang telah tertanam sedari dahulu kala.

\section{SIMPULAN}

Penelitian ini memperoleh hasil bahwa gaya kepemimpinan transformasional ternyata tidak berpengaruh pada kinerja keuangan LPD di Kota Denpasar. Terlihat bahwa koordinasi antara bawahan dan pemimpin tidak berjalan dengan baik, sehingga karyawan tidak memberikan umpan balik dan respon atas kebijakan-kebijakan yang dibuat oleh pemimpinnya.Namun demikian, budaya Tri Hita Karana ternyata mampu meningkatkan kinerja keuangan.Budaya Tri Hita Karana yang merupakan falsafah hidup masyarakat Bali sangat mudah untuk dipahami dan dilaksanakan dalam kegiatan organisasi.Hal ini secara langsung meningkatkan kinerja karena adanya kesamaan tujuan individu dan 
tujuan organisasi.Penelitian selanjutnya diharapkan mampu memperluas cakupan wilayah penelitian, tidak hanya terfokus pada Kota Denpasar saja. Selain itu, jika dilihat dari nilai koefisien determinasi, terlihat bahwa variabel dalam penelitian ini hanya mampu menjelaskan $0,01 \%$ dari variasi kinerja keuangan, sehingga penelitian selanjutnya dapat menggunakan variabel lain yang memang lebih memberikan kontribusi dalam variasi kinerja keuangan.

\section{REFERENSI}

Arifin, H. M. (2015). The influence of competence, motivation, and organisational culture to high school teacher job satisfaction and performance. International Education Studies, 8(1), 38-45. https://doi.org/10.5539/ies.v8n1p38

Asmara, J., \& Widanaputra, A. A. G. P. (2017). Pengaruh Gaya Kepemimpinan Transformasional dan Budaya Organisasi Pada Kinerja Organisasi dengan Motivasi Kerja sebagai Pemoderasi. E-Jurnal Akuntansi Universitas Udayana, 18(2), 1575-1603.

Astuti, Y. F. (2015). Pengaruh gaya kepemimpinan transformasional dan kompensasi terhadap kinerja karyawan pada. Skripsi. Sarjana Jurusan Manajemen Fakultas Ekonomi Universitas Negeri Yogyakarta.

Atkinson, P., \& Mackenzie, R. (2015). Without leadership there is no change. Management Services, 59(2), 42-47.

Einolander, J. (2015). Evaluating Organizational Commitment in Support of Organizational Leadership. Procedia Manufacturing, 3, 668-673. https://doi.org/10.1016/j.promfg.2015.07.300

Giddens, J. (2018). Transformational leadership: What every nursing dean should know. Journal of Professional Nursing, 34(2), 117121.https:/ / doi.org/10.1016/j.profnurs.2017.10.004

Gunawan, K. (2009). Pengaruh Budaya Organisasi, Kepuasan Kerja Dan Motivasi Kerja Terhadap Gaya Kepemimpinan Dan Kinerja Organisasi (Studi Pada Lembaga Perkreditan Desa (LPD) Di Bali). Jurnal Aplikasi Manajemen, 7(2), 441-449.

Hao, M. J., \& Yazdanifard, R. (2015). How Effective Leadership can Facilitate Change. Global Journal of Management and Business Research: A Administration and Management, 15(9), 0-6.

Hasibuan, M. S. . (2009). Manajemen Sumber Daya Manusia. Jakarta: Bumi Aksara.

Hunt, T. J. (2014). Leader-member exchange relationships in health information management. Perspectives in Health Information Management / AHIMA, American Health Information Management Association, 11(1), 1-8.

Ingdanata, D. P. (2017). Pengaruh Good Corporate Governance dan Love of Money Pada Kinerja Keuangan Bank Perkreditan Rakyat di Kota Denpasar. Skripsi. Sarjana Jurusan Akuntansi Fakultas Ekonomi dan Bisnis Universitas Udayana.

Joseph, O. O., \& Kibera, F. (2019). Organizational Culture and Performance: Evidence From Microfinance Institutions in Kenya. SAGE Open, 9(1), 1-11. https://doi.org/10.1177/2158244019835934

Jyoti, J., \& Bhau, S. (2016). Empirical investigation of moderating and mediating variables in between transformational leadership and related outcomes: A study of higher education sector in North India. International Journal of 
Educational Management, 30(6), 1123-1149. https:/ / doi.org/10.1108/IJEM-012015-0011

Kartika, I. N., \& Jember, I. M. (2017). Sanksi Adat pada Lembaga Pekreditan Desa dalam Kerangka Principal-Agent LPD (Lembaga Perkriditan Desa) SeKecamatan Tembuku Kabupaten Bangli. Jurnal Ekonomi Kuantitatif Terapan, 10(2), 183-191.

Keay, A. (2017). Stewardship theory: is board accountability necessary? International Journal of Law and Management, 59(6), 1292-1314. https://doi.org/10.1108/ijlma-11-2016-0118

Kouszes, J. ., \& Posner, B. Z. (2004). Leadership The Challenge: Tantangan Kepemimpinan (3rd ed.). Jakarta: Erlangga.

Madison, K. J. (2014). Agency Theory and Stewardship Theory Integrated, Expanded, and Bounded by Context: An Empirical Investigation of Structure, Behavior, and Performance within Family Firms. University of Tennessee,Knoxville, 1-160. https:// doi.org/10.17129/botsci.8

Parlinda, V., \& Wahyuddin, M. (2004). Pengaruh Kepemimpinan, Motivasi, Pelatihan, Dan Lingkungan Kerja Terhadap Kinerja Karyawan Pada Perusahaan Daerah Air Minum Kota Surakarta. UDiNus Repository.

Pertiwi, T. K., \& Pratama, F. M. I. (2011). Pengaruh Kinerja Keuangan, Good Corporate Governance Terhadap Nilai Perusahaan Food and Beverage. Jurnal Manajemen Dan Kewirausahaan, 14(2). https:// doi.org/10.9744/jmk.14.2.118-127

Pratiwi, N. K. L. A., \& Erawati, N. M. A. (2017). Kepuasan Kerja Memoderasi Gaya Kepemimpinan Transformasional Dan Budaya Organisasi Berbasis THK Pada Kinerja Organisasi. E-Journal Akuntansi Universitas Udayana, 21(3), 1848-1872. https:// doi.org/10.1017/CBO9781107415324.004

Riana, I. G. (2011). Dampak Penerapan Kultur Lokal Tri Hita Karana terhadap Orientasi Kewirausahaan dan Orientasi Pasar. Jurnal Teknik Industri, 13(1), 37-44. https:// doi.org/10.9744/jti.13.1.37-44

Risqi, R. O., Ushada, M., \& Supartono, W. (2015). Analisis Pengaruh Kepuasan Kerja Terhadap Kinerja Karyawan Dengan Pendekatan Kansei Engineering Perusahaan XYZ. Agritech, 35(1), 78-87.

Rosmiyati, R. (2013). Pengaruh Gaya Kepemimpinan, Motivasi, dan Budaya Organisasi terhadap Kinerja Karyawan. Tesis. Fakultas Ekonomika dan Bisnis Universitas Gadjah Mada.

Saputra, K. A. K. (2012). Pengaruh Locus of Control Terhadap Kinerja Dan Kepuasan Kerja Internal Auditor Dengan Moderasi. Jurnal Akuntansi Multiparadigma, 3(1), 86-100.

Satyawati, N. M. R., \& Suartanna, I. W. (2014). Pengaruh Gaya Kepemimpinan dan Budaya Organisasi terhadap Kepuasan Kerja yang Berdampak pada Kinerja Keuangan. E-Jurnal Akuntansi Universitas Udayana, 6(1), 17-32. https://doi.org/10.11669/cpj.2015.18.004

Solomon, A., \& Steyn, R. (2017). Leadership style and leadership effectiveness: Does cultural intelligence moderate the relationship? Acta Commercii, 17(1), 1-13. https://doi.org/10.4102/ac.v17i1.453

Suardhika, I. M. S., Sutrisno, Sukoharsono, E. G., \& Purnomosidhi, B. (2012). Pengaruh Implementasi Budaya Tri Hita Karana Terhadap Penggunaan 
Sistem Informasi Akuntansi Dimediasi Keyakinan-Diri Atas Komputer, Keinovatifan Personal, Persepsi Kegunaan, Dan Persepsi Kemudahan Penggunaan Pada Bank Perkreditan Rakyat Di Bali. SNA XV Universitas Lambung Mangkurat Banjarmasin, 1-45.

Suartana, I. W. (2013). Risk Based Audit Berbasis Budaya pada Lembaga Perkreditas Desa (LPD) Menuju Inklusi Keuangan Berkelanjutan. Jimbaran.

Subramanian, S. (2018). Stewardship Theory of Corporate Governance and Value System: The Case of a Family-owned Business Group in India. Indian Journal of Corporate Governance, 11(1), 88-102. https://doi.org/10.1177/0974686218776026

Suharyanto. (2011). Pengaruh Kepemimpinan dan Budaya Organisasi Terhadap Kinerja Pegawai. Jurnal Statistika, 4(2), 15-25. https://doi.org/10.29259/jmbs.v16i3.7381

Susantoso, J. (2013). Pengaruh Gaya Kepemimpinan, Lingkungan Kerja Dan Budaya Organisasi Terhadap Kinerja Pegawai Dengan Mediasi Kepuasan Kerja Di Dinas Pendapatan, Pengelolaan Keuangan Dan Aset Daerah Kabupaten Pati. Universitas Muria Kudus.

Tianya, L. (2015). Organizational Culture \& Employee Behavior: Case study. Lahden Ammattikorkeakoulu Lahti University of Applied Science, 1-53.

Vveinhardt, J., \& Andriukaitiene, R. (2017). Management culture as part of organizational culture in the context of corporate social responsibility implementation. Economics and Sociology, 10(3), 294-320. https://doi.org/10.14254/2071-789X.2017/10-3/21

Yukl, G. (2013). Leadership In Organizations (8th ed.). Albany: Pearson. 